\title{
Detection of autoantibodies in a point-of-care rheumatology setting
}

\author{
Konstantin N. Konstantinov • Antonios Tzamaloukas • \\ Robert L. Rubin
}

Received: 28 January 2013/Accepted: 2 May 2013/Published online: 18 May 2013

(C) Springer-Verlag Italia 2013

\begin{abstract}
Autoimmune rheumatic diseases are common and confront society with serious medical, social, and financial burdens imposed by their debilitating nature. Many autoimmune diseases are associated with a particular set of autoantibodies, which have emerged as highly useful to define and classify disease, predict flares, or monitor efficacy of therapy. However, current practice for monitoring autoantibodies is protracted, labor-intensive, and expensive. This review provides an overview on the value of point-of-care (POC) biosensor technology in the diagnosis and management of patients with autoimmune rheumatic diseases. Real-time measurement of autoantibodies will clearly benefit the rheumatology practice in emergency and urgent care settings, where definitive diagnosis is essential for initiation of correct critical care therapy. Immediate serological information in clinic will provide considerable value for long-term patient care and an opportunity for
\end{abstract}

K. N. Konstantinov $(\bowtie)$

Division of Rheumatology, Department of Internal Medicine,

University of New Mexico Health Sciences Center,

Mail Stop MSC10-5550, Albuquerque,

NM 87131, USA

e-mail: kkonstantinov@salud.unm.edu

\section{A. Tzamaloukas}

Renal Section, Raymond G. Murphy VA Medical Center,

1501 San Pedro SE, Albuquerque, NM 87108, USA

R. L. Rubin

Department of Molecular Genetics and Microbiology,

MCS08-4660, University of New Mexico Health

Sciences Center, Albuquerque, NM 87131, USA an instant, result-deduced therapeutic action, avoiding delays and improving compliance, especially in fieldbased and remote areas. We describe the particular autoantibodies that are useful disease and activity markers and would, therefore, be attractive to POC applications. Already existing biosensors and platforms that show promise for autoantibody testing are summarized and comparatively evaluated. As POC assessment is gaining momentum in several areas of patient care, we propose that rheumatology is poised to benefit from this innovative and affordable technology.

Keywords Point-of-care (POC) testing - Autoantibodies · Autoimmunity $\cdot$ Rheumatic diseases

$\begin{array}{ll}\begin{array}{ll}\text { Abbreviations } \\ \text { ADAMTS13 }\end{array} & \begin{array}{l}\text { A desintegrin and metalloproteinase with a } \\ \text { trombospondin type 1 motif, member 13 }\end{array} \\ \text { ANCA } & \text { Anti-neutrophil cytoplasmic antibodies } \\ \text { APL } & \text { Anti-phospholipid } \\ \text { CCP } & \text { Cyclic citrullinated peptide } \\ \text { CRP } & \text { C-reactive protein } \\ \text { DFS70 } & \text { Dense fine speckles 70 kDa } \\ \text { DVT } & \text { Deep venous thrombosis } \\ \text { GBM } & \text { Glomerular basement membrane } \\ \text { MCV } & \text { Mutated citrullinated vimentin } \\ \text { MPO } & \text { Myeloperoxidase } \\ \text { NMDA-R } & \text { N-methyl-D-aspartate receptor } \\ \text { NPSLE } & \text { Neuropsychiatric systemic } \\ & \text { lupus erythematosus } \\ \text { POC } & \text { Point-of-care } \\ \text { PR3 } & \text { Proteinase 3 } \\ \text { RA } & \text { Rheumatoid arthritis } \\ \text { RF } & \text { Rheumatoid factor } \\ \text { SLE } & \text { Systemic lupus erythematosus }\end{array}$


Autoimmune rheumatic diseases afflict $2-3 \%$ of the population [1] and create enormous burden on individuals and society due to poor quality of life and lower productivity [2]. This heterogeneous group of clinical conditions are typically linked by the presence of autoantibodies directed against self-constituents. Often, serum autoantibodies are the only objective serological markers for an underlying rheumatic disease and as such, are part of classification criteria developed to provide a common language for diagnosis, monitoring, therapeutic trials, and international publications. While patient history and physical examination are the cornerstone of the differential diagnosis, current practice analysis shows that most clinicians readily act only after receiving confirmatory or exclusionary laboratory test results $[3,4]$.

Traditionally, the consultative and diagnostic services in rheumatology are not considered clinical emergencies that would require same-day diagnostic or clinical decisions. While this may hold true for chronic and non-inflammatory conditions, it should also be recognized that most inflammatory and autoimmune conditions that constitute a major part of academic or private rheumatology practice have to be diagnosed and acted upon quickly to curb irreversible immune-mediated damage and mortality. This is especially true for patients whose management includes critical care and aggressive therapy after diagnosis. Currently, it is necessary to use the services of centralized laboratories to obtain this information, which can delay diagnosis and appropriate treatment.

It has been estimated that $10-25 \%$ of all patients with rheumatologic disorders visiting the emergency departments require hospital admission, and up to one-third of the hospitalized patients need intensive care [5, 6]. These emergencies may present as a rapidly evolving and confusing multisystem organ failure, can mimic other conditions or initially mislead with deceptively benign clinical signs. High level of suspicion, clinical knowledge, and detection of circulating autoantibody markers contribute significantly to a timely diagnosis. Table 1 summarizes the use of specific autoantibody testing for the diagnostic process in acute clinical settings. Test selection and interpretation of results is often dependent on the observed clinical complexity, but a characteristic combination of particular clinical and timely laboratory features help to refine the pretest assessment of disease probability. Both positive and negative predictive values of a test result may be useful. For example, a patient visiting the ER with extensive palpable purpura may trigger suspicion of systemic vasculitis, which could be directly supported by a positive ANCA test. Unfortunately, laboratory tests for autoimmune disorders require significant processing time; most autoimmune serology tests performed in reference laboratories take at least several days. Turnaround times for tests ordered by practices in remote or outreach clinics are longer, as much as 7 days.

The outpatient rheumatology practice of dealing with autoimmune conditions collides with a different problem: assessing active disease resulting in progressive organ damage and early mortality. Establishing reliable biomarkers that accurately predict disease activity is a major challenge faced by practicing physicians. Such tests should be clinically meaningful, affordable, and easy, and should distinguish cross-sectional differences between patients with active and inactive disease as well as longitudinal changes in disease expression or activity in individual patients [7].

Quantitative measures of autoimmune activity, in contrast to critical care analytes, are generally not considered important in the biomarker field, as changes in autoantibody concentration are believed to be slow and of minor importance to the patient outcome. This misconception is particularly apparent in the rapid humoral immune response observed in autoimmune loop conditions like SLE and antiphospholipid syndrome [8, 9]. However, serial and routine testing in a cost-effective and readily accessible way requires technology and assays that currently do not exist.

Previous research suggests that some of the autoantibodies listed in Table 1 as diagnostic aids behave like parameters that wax and wane with disease activity, thus holding promise to provide prognostic clinical information and, when at their best, to guide therapy. When target organ involvement is considered, autoantibodies may correlate with important clinical outcomes. Current candidate autoantibody disease activity markers are summarized in Table 2. The more recently described value of regular autoantibody "profiling" in patients with Wegener's granulomatosis due to change in epitope specificity of PR3ANCA during active disease [10] and the association of high and low anti-NMDA-R autoantibody titers with unique CNS symptoms in neuropsychiatric SLE [11] underscores the importance of autoantibody assays for optimal management.

It is beyond the scope of this paper to discuss discrepancies observed among studies that characterize autoantibodies as disease activity markers. Many believe that lack of prospective or longitudinal studies, clearly defined methodology, patient selection bias, use of inconsistent definitions for disease activity, frequency of testing, and effects of therapy contribute to conflicting results $[12,13]$. It should also be noted that disease activity, disease severity, and the ensuing irreversible damage should be conceptually differentiated, and measurement tools for these parameters may be different [14]. Despite these potential problems in interpreting laboratory results, the need of clinicians to judge disease activity has made the 
Table 1 Autoimmune serology assessment for possible rheumatic disease in emergency settings

\begin{tabular}{|c|c|c|}
\hline Symptom & Positive test result & Disease \\
\hline \multicolumn{3}{|l|}{ Airway problems } \\
\hline Hemoptysis & Anti-dsDNA, other lupus serologies & Alveolar hemorrhage in SLE \\
\hline Airflow obstruction & Anti-CCP, RF & $\begin{array}{l}\text { Cricoarytenoid arthritis in rheumatoid } \\
\text { arthritis (RA) }\end{array}$ \\
\hline $\begin{array}{l}\text { Mucopurulent rhinorrhea; subglottic } \\
\text { stenosis; hypopharyngeal } \\
\text { ulcerations }\end{array}$ & $\begin{array}{l}\text { Anti-neutrophil cytoplasmic antibodies } \\
\text { (ANCA, MPO or PR3) }\end{array}$ & Wegener's granulomatosis \\
\hline Stridor, laryngotracheal strictures & Anti-type II collagen & Relapsing polychondritis \\
\hline Acute pneumonitis & Anti-dsDNA, other lupus serologies & SLE \\
\hline \multicolumn{3}{|l|}{ Pulmonary-renal problems } \\
\hline $\begin{array}{l}\text { Pulmonary hemorrhage and acute } \\
\text { renal failure }\end{array}$ & Anti-GBM, MPO-ANCA, PR3-ANCA & Goodpasture's syndrome; systemic vasculitis \\
\hline \multicolumn{3}{|l|}{ Neuropsychiatric problems } \\
\hline $\begin{array}{l}\text { Encephalopathy, psychosis, focal } \\
\text { central nervous system disease }\end{array}$ & $\begin{array}{l}\text { Anti- } N \text {-methyl-D-aspartate receptor (NMDA-R), anti- } \\
\text { ribosomal P antibodies, antiphospholipid antibodies }\end{array}$ & $\begin{array}{l}\text { Neuropsychiatric SLE, antiphospholipid } \\
\text { syndrome }\end{array}$ \\
\hline $\begin{array}{l}\text { Weakness, paralysis, bilateral sensory } \\
\text { deficit, impaired sphincter control }\end{array}$ & Lupus serologies & Transverse myelitis in SLE \\
\hline Seizures & Anti-dsDNA, other lupus serologies & Lupus cerebritis \\
\hline \multicolumn{3}{|l|}{ Thromboembolic problems } \\
\hline $\begin{array}{l}\text { DVT, pulmonary thromboembolism, } \\
\text { fetal loss, retinal artery occlusion }\end{array}$ & Anti-phospholipid antibodies & Antiphospholipid syndrome \\
\hline \multicolumn{3}{|l|}{ Neuromuscular problems } \\
\hline $\begin{array}{l}\text { Progressive symmetric muscle } \\
\text { weakness; dysphagia; dysphonia }\end{array}$ & Anti-Jo-1, other myositis-specific autoantibodies & Dermatomyositis, polymyositis \\
\hline Unusual weakness and hypokalemia & Anti-Ro/SSA; anti-La/SSB & Sjogren's syndrome hypokalemic paralysis \\
\hline \multicolumn{3}{|l|}{ Cardiac problems } \\
\hline $\begin{array}{l}\text { Pleuritic or positional chest pain, } \\
\text { dyspnea, tachycardia }\end{array}$ & $\begin{array}{l}\text { Anti-dsDNA, other lupus serologies, Anti- } \\
\text { phospholipid antibodies }\end{array}$ & $\begin{array}{l}\text { SLE pleuro-pericarditis, pericardial } \\
\text { tamponade }\end{array}$ \\
\hline $\begin{array}{l}\text { Congenital heart block; neonatal } \\
\text { carditis }\end{array}$ & Anti-Ro/SSA; anti-La/SSB & Neonatal SLE \\
\hline \multicolumn{3}{|l|}{ Renal problems } \\
\hline Rapidly progressive renal failure & $\begin{array}{l}\text { MPO-ANCA, PR3-ANCA, anti-dsDNA and other } \\
\text { lupus serologies, anti-phospholipid antibodies }\end{array}$ & $\begin{array}{l}\text { Microscopic polyangiitis, WG, lupus } \\
\text { nephritis, catastrophic antiphospholipid } \\
\text { syndrome }\end{array}$ \\
\hline Accelerated hypertension & $\begin{array}{l}\text { Anti-Scl-70; anti-centromeres, anti-RNA-Polymerase } \\
\text { III }\end{array}$ & Renal crisis in systemic sclerosis \\
\hline \multicolumn{3}{|l|}{ Joint problems } \\
\hline $\begin{array}{l}\text { Pain, stiffness, swelling with } \\
\text { symptoms of systemic disease }\end{array}$ & Anti-CCP, RF and lupus serologies & RA, SLE \\
\hline \multicolumn{3}{|l|}{ Ocular problems } \\
\hline Red, painful, photophobic eye & $\mathrm{RF}$, anti-CCP, lupus serologies & RA, Behcet's, juvenile RA, SLE \\
\hline \multicolumn{3}{|l|}{ Gastrointestinal problems } \\
\hline Colicky abdominal pain & Lupus serologies & SLE mesenteric arteritis \\
\hline \multicolumn{3}{|l|}{ Skin problems } \\
\hline $\begin{array}{l}\text { Petechiae, palpable purpura, } \\
\text { hemorrhagic blisters, ulcerations and } \\
\text { gangrene }\end{array}$ & SLE and RA serologies & SLE, rheumatoid vasculitis \\
\hline Neonatal skin rash & Anti-Ro/SSA, anti-La/SSB & Neonatal lupus \\
\hline \multicolumn{3}{|l|}{ Hematological problems } \\
\hline $\begin{array}{l}\text { Anemia, thrombocytopenia, } \\
\text { leukopenia }\end{array}$ & $\begin{array}{l}\text { Anti-DNA and lupus serologies; anti-erythrocyte, } \\
\text { anti-platelet antibodies }\end{array}$ & SLE, autoimmune hemolytic anemia \\
\hline Thrombocytopenia & Antiphospholipid antibodies & Antiphospholipid syndrome \\
\hline
\end{tabular}


Table 2 Associations between autoantibody changes and disease activity

\begin{tabular}{|c|c|c|c|}
\hline Disease/condition & Autoantibody & Change & Clinical prediction \\
\hline \multirow[t]{8}{*}{ Systemic lupus erythematosus } & Anti-dsDNA & $\Uparrow$ & Active flare [15-17] \\
\hline & Anti-dsDNA & $\Downarrow$ & Active flare [18] \\
\hline & Anti-nucleosome & $\Uparrow$ & Active disease/lupus nephritis [19-21] \\
\hline & Anti-C1q & $\Uparrow$ & Lupus nephritis [22-24]/active disease [25] \\
\hline & Anti-NMDA-R & $\Uparrow$ & Permanent CNS impairment $[26,27]$ \\
\hline & Anti-NMDA-R & $\Downarrow$ & Transient CNS symptoms $[26,27]$ \\
\hline & Anti-CRP & $\Uparrow$ & Lupus nephritis/response to therapy [28] \\
\hline & Anti-interferon- $\alpha$ & $\Downarrow$ & Inactive disease [29] \\
\hline \multirow[t]{3}{*}{ Systemic vasculitis } & Anti-PR3 & $\Uparrow$ & Active disease/disease relapse [30-32] \\
\hline & Anti-MPO & $\Uparrow$ & Active disease/disease relapse $[33,34]$ \\
\hline & Anti-GBM & $\Uparrow$ & Active disease/disease relapse $[35,36]$ \\
\hline Scleroderma & Anti-topoisomerase I & $\Uparrow$ & Active scleroderma [37-39] \\
\hline Rheumatoid arthritis & Anti-drug (adalimumab) & $\Uparrow$ & Treatment failure [40] \\
\hline Antiphospholipid syndrome/SLE & Anti-phospholipid & $\Uparrow$ & Procoagulant state, thrombosis [41-43] \\
\hline Necrotizing myopathy & Anti-signal recognition particle & $\Uparrow$ & $\begin{array}{l}\text { Decreased muscle strength, } \\
\text { increased creatine kinase activity [44] }\end{array}$ \\
\hline Thrombotic thrombocytopenic purpura & Anti-ADAMTS13 antibodies & $\Uparrow$ & Disease relapse $[45,46]$ \\
\hline \multirow[t]{2}{*}{ Pregnancy in SLE } & Anti-Ro(SSA)/anti-Ro52 & $\Uparrow$ & Congenital heart block $[47,48]$ \\
\hline & Anti-La(SSB) & $\Uparrow$ & Neonatal lupus [49] \\
\hline Autoantibody serum screening & Anti-DFS70 & $\Uparrow$ & ANA-positive healthy individuals $[50,51]$ \\
\hline
\end{tabular}

practice of ordering autoantibodies widespread and frequent, with $92 \%$ of US rheumatologists using serial antidsDNA autoantibody titers to monitor disease activity in SLE [4].

New technologies, that deliver quantitative information in a simple, fast, and low-cost fashion when combined with frequent visits and blood sampling may provide for the first time a tool to definitively establish the predictive value of autoantibody fluctuations in disease flares. Point-of-care (POC) testing, otherwise referred as near patient, bedside or extra-laboratory testing for clinically important analytes, has gathered strength in diverse medical specialties. By virtue of its near real-time data collection capability, POC testing has the potential to change the paradigm in the practice of medicine, and we anticipate that rheumatology will not be an exception.

Devising a reliable assay for measuring a specific antibody in human serum is more difficult than measuring most non-antibody analytes in biological fluids, because any one antibody specificity is usually a tiny fraction of total serum immunoglobulin. Non-specific binding of immunoglobulin may have impeded the development of a reliable antibody biosensor. However, recent and evolving advances in the field of immunosensor technologies have provided high accuracy in quantification and low detection limit in testing for some autoantibodies used in clinical practice.

Current POC immunoassay technologies come in various configurations and complexities. Table 3 provides a partial list of new biosensors and their platforms that have the potential to measure autoantibodies in "real" clinical samples. Surface plasmon resonance-based sensors are the most rapid method, but will require adaptation to inexpensive miniaturized devices. Lateral flow based methods will probably be restricted to non-quantitative readouts. Devices that required specialized antigen tags may have limited practical potential. Electrochemical amplification methods using readily available autoantigens are especially promising. Autoantibody biosensors have generally equaled or surpassed traditional central laboratory methods in performance metrics, such as sensitivity, specificity, and especially time to result. Advances in the development and application of portable, antibody-based immunosensors are presented in several recent review papers [52-56].

The American College of Rheumatology (ACR) has recognized the value of decentralized laboratory testing in their position statement on the issue [57] in which not only patient convenience (a single site for physician contact and serology testing), but also cost savings associated with return visits just to implement treatment options would be benefited. According to the ACR, rheumatologists, in directing their office laboratories, are the most qualified for determining the utility of specific tests, analyzing their results and applying these results to therapeutic situations. Immediate autoantibody diagnostics can also help to establish autoimmune disease units in hospitals, as recently suggested [58, 59]. 
Table 3 Devices with potential to measure autoantibodies (Ab) at point-of-care

\begin{tabular}{|c|c|c|c|}
\hline Autoantibody & $\begin{array}{l}\text { Detection } \\
\text { technology/assay platform }\end{array}$ & $\begin{array}{l}\text { Assay } \\
\text { duration }\end{array}$ & References \\
\hline \multirow[t]{3}{*}{ Anti-dsDNA } & Electrochemical reduction of redox-tagged probe/Ab inhibition in single-step cell & $\sim 45 \min$ & {$[60]$} \\
\hline & Decreased resonance frequency/piezoelectric quartz crystal microbalance & $<60 \min$ & {$[61]$} \\
\hline & Refractive index change/surface plasmon resonance sensor chip & $\sim 5 \min$ & {$[62]$} \\
\hline \multirow[t]{2}{*}{ Anti-CCP } & Formation of visual line by colored nanoparticles/lateral flow chromatography & $10 \mathrm{~min}$ & {$[66]$} \\
\hline & Refractive index change/surface plasmon resonance sensor chip & $\sim 5 \min$ & {$[67]$} \\
\hline Anti-chromatin & Peroxidase-mediated electrochemical amplification/flow-through cell & $20 \mathrm{~min}$ & {$[64]$} \\
\hline Anti-IgG (RF) Anti-MCV & Formation of visual line by colored nanoparticles/lateral flow chromatography & $15 \min$ & {$[65]$} \\
\hline $\begin{array}{l}\text { Anti-Ro/SSA, Anti-Ro52, } \\
\text { Anti-La/SSB }\end{array}$ & Luminescence by luciferase-tagged probe/bead immobilized $\mathrm{Ab}$ in two-step cells & $25 \mathrm{~min}$ & {$[63]$} \\
\hline Anti- $\beta 2$-glyco-protein I & Refractive index change/surface plasmon resonance sensor chip & $\sim 5 \min$ & {$[68]$} \\
\hline
\end{tabular}

Sites for POC serology testing could include outpatient rheumatology clinics, intensive care units, and emergency or urgent care facilities, as well as hospital infusion centers. Another attractive possibility is the use of POC serology testing in field-based, remote or rudimentary clinical settings, thereby bringing laboratory-based medicine to lowresource areas. In all these environments, POC devices would be of value to rheumatology physicians, who can immediately act on the information. In the outpatient clinic, a rapid test result could affect physician evaluation of the patient, thereby facilitating action and likely improving the usefulness of the office visit. POC methods should enhance patient compliance for laboratory testing and decrease the number of return visits. The efficiency and quality of health care from both the physician and the patient perspective is likely to improve as a result.

At this point it is unlikely that POC testing will replace the traditional central clinical laboratory model in all situations. Establishing rigid quality control of POC testing that satisfies regulatory requirements and oversight could be challenging. Handling and disposal of potentially biohazardous and chemical fluids may need to be addressed. Physical records, transfer of test results into a patient chart, and reimbursement issues will also play a major role in acceptance of POC technology.

POC serology testing is truly a work in progress, and its successful deployment requires a long-term commitment. The anti-CCP assay has recently been commercialized, but general acceptance of POC autoantibody testing in rheumatology has yet to happen. The optimum technology should be reliable, fast, inexpensive, quantitative, and easy to put in place and use. The latter features will make POC testing attractive to clinical rheumatology staff whose primary focus is patient care. Analyses of health care in the future predict that medicine will be more decentralized, and realization of POC testing has the promise to accelerate this paradigm shift for patient management.
Conflict of interest Konstantin N. Konstantinov, Antonios Tzamaloukas, Robert L. Rubin declare that they have no conflict of interest.

Informed Consent All procedures followed were in accordance with the ethical standards of the responsible committee on human experimentation (institutional and national) and with the Helsinki Declaration of 1975 , as revised in 2005. Informed consent was obtained from all patients for being included in the study.

Animal studies No animal studies were carried out by the authors for this article.

\section{References}

1. Jacobson DL, Gange SJ, Rose NR, Graham NM et al (1997) Epidemiology and estimated population burden of selected autoimmune diseases in the United States. Clin Immunol Immunopathol 84:223-243

2. Yelin E, Cisternas MG, Pasta DJ, Trupin L, Murphy L, Helmick CG (2004) Medical care expenditures and earning losses of persons with arthritis and other rheumatic conditions in the United States in 1997: total and incremental estimates. Arthritis Rheum 50:2317-2326

3. Epstein AM, McNell BJ (1986) Relationship of beliefs and behavior in test ordering. Am J Med 80:865-870

4. Donald F, Waed MM (1998) Evaluative laboratory testing practices of United States rheumatologists. Arthritis Rheum 41:725-729

5. Janssen NM, Karnad DR, Guntupalli KK (2002) Rheumatologic diseases in intensive care unit: epidemiology, clinical approach, management, and outcome. Crit Care Clin 18:729-748

6. Smarma M, Lelrisalo-Repo M (1997) Arthritis patient as an emergency case at a university hospital. Scand J Rheumatol 26:30-36

7. Tektonidou MG, Ward MM (2011) Validation of new biomarkers in systemic autoimmune diseases. Nat Rev Rheumatol 7:708-717

8. Ronnelid J, Huang YH, Norlander T, Rodberg S, Nilsson B, Gustafsson R et al (1994) Short-term kinetics of the humoral antiC1q response in SLE using the ELISPOT method: fast decline in production in response to steroids. Scand J Immunol 40:243-250

9. Out HJ, de Groot PG, Hasselaar P, dan Vliet M, Derksen RH (1989) Fluctuations of anticardiolipin antibody levels in patients with systemic lupus erythematosus: a prospective study. Ann Rheum Dis 48:1023-1028

10. Rarok AA, van der Geld YM, Stegeman CA, Limburg PC, Kallenberg CG (2003) Diversity of PR3-ANCA epitope specificity in 
Wegener's granulomatosis. Analysis using the biosensor technology. J Clin Immunol 23:460-468

11. Faust TW, Chang EH, Kowal C, Berlin R, Gazaryan IG, Bertini E et al (2010) Neurotoxic lupus autoantibodies alter brain function through two distinct mechanisms. Proc Natl Acad Sci USA 107:18569-18574

12. Wiik AS (2010) Autoantibodies in ANCA-associated vasculitis. Rheum Dis Clin N Am 36:479-489

13. Kavanaugh AF, Solomon DH (2002) American College of Rheumatology Ad Hoc Committee on Immunologic Testing Guidelines. Guidelines for immunologic laboratory testing in the rheumatic diseases: anti-DNA antibody tests. Arthritis Rheum 47:546-555

14. Guillermin F (2003) Assessment of disease activity. Best Practice Res Clin Rheum 17:415-426

15. Ter Borg EJ, Horst G, Hummel EJ, Limburg PC, Kallenberg CG (1990) Measurement of increases in anti-double-stranded DNA antibody levels as a predictor of disease exacerbation in systemic lupus erythematosus. Arthritis Rheum 33:634-643

16. Linnik MD, Hu JZ, Heilbrunn KR, Strand V, Hurley FL, Joh T et al (2005) Relationship between anti-double-stranded DNA antibodies and exacerbation of renal disease in patients with systemic lupus erythematosus. Arthritis Rheum 52:1129-1137

17. Pan N, Amigues I, Duculan R, Aziz F, Lyman SL, Crow MK et al (2011) Rapid surges of anti-dsDNA titers predict severe clinical flares in systemic lupus erythematosus. ACR, Chicago (presentation number 1709)

18. Ho A, Magder LS, Barr SG, Petri M (2001) Decreases in antidouble-stranded DNA levels are associated with concurrent flares in patients with systemic lupus erythematosus. Arthritis Rheum 44:2342-2349

19. Suleiman S, Kamaliah D, Nadeem A, Naing NN, Maraina CHC (2009) Anti-nucleosome antibodies as a disease activity marker in patients with systemic lupus erythematosus. Int J Rheum Dis 12:100-106

20. Kiss E, Lakos G, Szegedi G, Poor G, Szodoray P et al (2009) Anti-nucleosome antibody, a reliable indicator for lupus nephritis. Autoimmunity 42:393-398

21. Ng KP, Manson JJ, Rahman A, Isenberg DA et al (2006) Association of antinucleosome antibodies with disease flare in serologically active clinically quiescent patients with systemic lupus erythematosus. Arthritis Rheum 55:900-904

22. Akhter E, Burlingame RW, Seaman AL, Magder L, Petri M (2011) Anti-C1q antibodies have higher correlation with flares of lupus nephritis than other serum markers. Lupus 20:1267-1274

23. Meyer OC, Nicaise-Roland P, Cadoudal N, Grootenboer-Mignot S, Palazzo E, Hayem G et al (2009) Anti-C1q antibodies antedate patient active glomerulonephritis in patients with systemic lupus erythematosus. Arthritis Res Ther 11:R87

24. Moura CG, Lima I, Barbosa L, Athanazio D, Reis E, Reis M et al (2009) Anti-C1q antibodies: association with nephritis and disease activity in systemic lupus erythematosus. J Clin Lab Anal 23:19-23

25. Katsumata Y, Miyake K, Kawaguchi Y, Okamoto Y, Kawamoto M, Gono T et al (2011) Anti-C1q antibodies are associated with systemic lupus erythematosus global activity but not specifically with nephritis. Arthritis Rheum 63:2436-2444

26. Arinuma Y, Yanagida T, Hirohata S (2008) Association of cerebrospinal fluid anti-NR2 glutamate receptor antibodies with diffuse neuropsychiatric systemic lupus erythematosus. Arthritis Rheum 58:1130-1135

27. Yoshio T, Onda K, Nara H, Minota S (2006) Association of IgG anti-NR2 glutamate receptor antibodies in cerebrospinal fluid with neuropsychiatric systemic lupus erythematosus. Arthritis Rheum 54:675-681
28. Sjowall C, Zickert A, Skogh T, Wettero J, Gunnarsson I et al (2009) Serum levels of autoantibodies against C-reactive protein correlate with renal disease activity and response to therapy in lupus nephritis. Arthritis Res Ther 11:R188

29. Morimoto AM, Flesher DT, Yang J, Wolslegel K, Wang X, Brady A et al (2011) Association of endogenous anti-interferon- $\alpha$ autoantibodies with decreased interferon-pathway and disease activity in patients with systemic lupus erythematosus. Arthritis Rheum 63:2407-2415

30. Sanders J-SF, Huitma MG, Kallenberg CGM, Stegeman CA (2006) Prediction of relapses in PR3-ANCA-associated vasculitis by assessing responses of ANCA titres to treatment. Rheumatology 45:724-729

31. Stegeman CA (2002) Anti-neutrophil cytoplasmic antibody (ANCA) levels directed against proteinase-3 and myeloperoxidase are helpful in predicting disease relapse in ANCA-associated small-vessel vasculitis. Nephrol Dial Transplant 17:2077-2080

32. Hogan SL, Falk RJ, Chin H, Cai J, Jennette C, Jennette JC et al (2005) Predictors of relapse and treatment resistance in antineutrophil cytoplasmic antibody-associated small-vessel vasculitis. Ann Intern Med 143:621-631

33. Terrier B, Saadoun D, Sene D, Ghillani P, Amoura Z, Deray G et al (2009) Antimyeloperoxidase antibodies are a useful marker of disease activity in antineutrophil cytoplasmic antibody-associated vasculitides. Ann Rheum Dis 68:1564-1571

34. Han WK, Choi HK, Roth RM, McCluskey RT, Niles JL et al (2003) Serial ANCA titers: useful tool for prevention of relapses in ANCA-associated vasculitis. Kidney Int 63:1079-1085

35. Zhao J, Cui Z, Yang R, Jia X, Zhang Y, Zhao M et al (2009) Anti-glomerular basement membrane autoantibodies against different target antigens are associated with disease severity. Kidney Int 76:1108-1115

36. Rutgers A, Heeringa P, Damoiseaux JG, Cohen Tervaert JW et al (2003) ANCA and anti-GBM antibodies in diagnosis and followup of vasculitic disease. Eur J Intern Med 14:287-295

37. Hu PQ, Fertig N, Medsger TA Jr, Wright TM (2003) Correlation of serum anti-DNA topoisomerase I antibody levels with disease severity and activity in systemic sclerosis. Arthritis Rheum 48:1363-1373

38. Kuwana M, Kaburaki J, Mimori T, Kawakami Y, Tojo T (2000) Longitudinal analysis of autoantibody response to topoisomerase I in systemic sclerosis. Arthritis Rheum 43:1074-1084

39. Hanke K, Dahnrich C, Bruckner CS, Huscher D, Becker M, Jansen A et al (2009) Diagnostic value of anti-topoisomerase I antibodies in a large monocentric cohort. Arthritis Res Ther 11:R28

40. Bartelds GM, Krieckaert CLM, Nurmohamed MT, van Schouwenburg PA, Lems WF, Twisk JWR et al (2011) Development of antidrug antibodies against adalimumab and association with disease activity and treatment failure during long-term follow-up. JAMA 305:1460-1468

41. Wilson WA, Gharavi AE, Koike T, Lockshin MD, Ware Branch D, Piette J-C et al (1999) International consensus statement on preliminary classification criteria for definitive antiphospholipid syndrome. Arthritis Rheum 42:1309-1311

42. Escalante A, Brey RB, Mitchell BD, Dreiner U (1995) Accuracy of anti-cardiolipin antibodies in identifying a history of thrombosis among patients with systemic lupus erythematosus. Am J Med 98:559-565

43. Lopez LR, Dier KJ, Lopez D, Merrill JT, Fink CA (2004) Anti$\beta_{2}$-glycoprotein I and antiphosphatidylserine antibodies are predictors of arterial thrombosis in patients with antiphospholipid syndrome. Am J Clin Pathol 121:142-149

44. Benveniste O, Drouot L, Jouen F, Charuel J-L, Bloch-Queyrat C, Behin A et al (2011) Correlation of anti-signal recognition particle 
autoantibody levels with creatine kinase activity in patients with necrotizing myopathy. Arthritis Rheum 63:1961-1971

45. Peyvandi F, Lavoretano S, Palla R, Feyes HB, Vanhoorelbeke K, Battagliolo $\mathrm{T}$ et al (2008) ADAMTS13 and anti-ADAMTS13 antibodies as markers for recurrence of acquired thrombotic thrombocytopenic purpura during remission. Haematologica 93:232-239

46. Lammle B, Kremer Hovinga JA, George JN (2008) ADAMTS13 activity, anti-ADAMTS13 autoantibodies and risk of recurrent disease. Haematologica 93:172-177

47. Jaeggi E, Laskin C, Hamilton R, Kingdom J, Silverman E (2010) The importance of the level of maternal anti-Ro/SSA antibodies as a prognostic marker of the development of cardiac neonatal lupus erythematosus. J Am Coll Cardiol 55:2778-2784

48. Strandberg L, Winqvist o, Sonesson S-E, Mohseni S, Salomonsson S, Bremme $\mathrm{K}$ et al (2008) Antibodies to amino acid 200-239 (p200) of Ro52 as a serological markers for the risk of developing congenital heart block. Clin Exp Immunol 154:30-37

49. Silverman ED, Buyon J, Laxer RM, Hamilton R, Bini P, Chu J-L et al (1995) Autoantibody response to the Ro/La particle may predict outcome in neonatal lupus erythematosus. Clin Exp Immunol 100:499-505

50. Watanabe A, Kodera M, Siguira K, Usuda T, Tan EM, Takasaki Y et al (2004) Anti-DFS70 antibodies in 597 healthy hospital workers. Arthritis Rheum 50:892-900

51. Mariz HA, Sato EI, Barbosa SH, Rodrigues SH, Dellavance A, Andrade LEC (2011) Pattern on antinuclear antibody-Hep-2 test is a critical parameter for discriminating antinuclear antibodypositive healthy individuals and patients with autoimmune rheumatic diseases. Arthritis Rheum 63:191-200

52. Gibson DS, Rooney ME, Finnegan S, Qiu J, Thomson DC, LaBaer $\mathbf{J}$ et al (2012) Biomarkers in rheumatology, now and in the future. Rheumatology 51:423-433

53. Pakkila H, Soukka T (2011) Simple and inexpensive immunoassay-based diagnostic tests. Bioanal Rev 3:27-40

54. D'Orazio P (2011) Biosensors in clinical chemistry-2011 update. Clin Chim Acta 412:1749-1761

55. Choi S, Goryll M, Sin LYM, Wong PK, Chae J et al (2011) Microfluidic-based biosensors toward point-of-care detection of nucleic acid and proteins. Microfluid Nanofluid 10:231-247

56. von Lode P (2005) Point-of-care immunotesting: approaching the analytical performance of central laboratory methods. Clin Biochem 38:591-606

57. American College of Rheumatology (2005) Clinical laboratory testing position statement. American College of Rheumatology, Atlanta
58. Vasconcelos C (2009) Do we need autoimmune disease units in hospitals? Ann N Y Acad Sci 1173:4-9

59. Shoenfeld Y, Selmi C, Zimlichman E, Gershwin ME (2008) The autoimmunologist: geoepidemiology, a new center of gravity, and a prime time for autoimmunity. J Autoimmun 31:325-330

60. Ricci F, Adornetto G, Moscone D, Plaxco KW, Palleschi G (2010) Quantitative, reagentless, single-step electrochemical detection of anti-DNA antibodies directly in blood serum. Chem Commun 46:1742-1744

61. Fakhrullin RF, Vinter VG, Zamaleeva AI, Matveeva MV, Kourbanov RA, Temesgen BK et al (2007) Quartz crystal microbalance immunosensor for the detection of antibodies to doublestranded DNA. Anal Bioanal Chem 388:367-375

62. Buhl A, Metzger JH, Heegard NHH, Von Landenberg P, Fleck M, Luppa PB (2007) Novel biosensor-based analytic device for the detection of anti-double-stranded DNA antibodies. Clin Chem 53:334-341

63. Burbelo PD, Ching KH, Issa AT, Loftus CM, Li Y, Sato M et al (2009) Rapid serological detection of autoantibodies associated with Sjogren's syndrome. J Transl Med 7:83-90

64. Konstantinov KN, Stdikov RA, Lopez GP, Atanassov P, Rubin RL (2009) Rapid detection of anti-chromatin autoantibodies in human serum using a portable electrochemical biosensor. Biosens Bioelectron 7:1949-1954

65. Renger F, Bang H, Feist E, Fredenhagen G, Natusch A, Backhaus $M$ et al (2010) Immediate determination of ACPA and rheumatoid factor-a novel point of care test for detection of anti-MCV antibodies and rheumatoid factor using a lateral-flow immunoassay. Arthritis Res Ther 12:R120

66. Liao J, Ip W, Cheung K, Wan W, Cautherley GWH, Cai X et al (2011) Diagnostic utility of an anti-CCP point-of-care immunotest in Chinese patients with rheumatoid arthritis. Clin Chim Acta 412:778-781

67. Lokate AMC, Beusink JB, Besselink GAJ, Pruijn GJM, Schasfoort RBM (2007) Biomolecular interaction monitoring of autoantibodies by scanning surface plasmon resonance microarray imaging. J Am Chem Soc 129:14013-14018

68. Metzger J, von Landenberg P, Kehrel M, Buhl A, Lackner K, Luppa PB (2007) Biosensor analysis of $\beta 2$-glycoprotein I-reactive autoantibodies: evidence for isotype-specific binding and differentiation of pathogenic from infection-induced antibodies. Clin Chem 53:1137-1143 